\title{
Early childhood education and care: poverty and access. Perspectives from England
}

\section{Chapter for SAGE Handbook of Early Childhood Policy (2017)}

\author{
Eva Lloyd
}

\section{Introduction}

English early childhood education and care provision (ECEC) has featured on governmental policy agendas and benefitted from public funding for a long time compared to ECEC in other high- and medium-income nations. Yet, the recent history of ECEC policy change in England illustrates how shifts in the relative weight accorded to different policy aims over time may have far-reaching consequences for children in low-income families' access to high quality provision (Penn, 2009; Moss, 2014a). This relates to their access within the private-for-profit childcare market, a prominent feature of the English early childhood service system, as much as to access to early childhood education within state funded primary and nursery schools (Mathers and Smees, 2014; Gambaro et al., 2013).

The decision to focus on English data in this chapter stems from the similarities and differences that characterise the ECEC policy and funding systems of the four nations making up the UK. After 1998, when a Devolution Act was implemented (HM Government, 2013), local jurisdictions gained the power to legislate in the area of 
early education policy and practice, notably around the size of the early education entitlement, the curriculum, workforce qualifications and funding streams (Fitzgerald and Kay, 2016). Recent early education policy change In England has often preceded that in the other UK jurisdictions, although within the four systems similarities outweigh difference. In contrast, responsibility for childcare policy and funding mechanisms via the tax and benefits systems remains the responsibility of central government departments and there are no national differences in this respect. Although developments in early education policy implementation in Wales, Scotland and Northern Ireland are intrinsically interesting, an English ECEC case study was deemed adequate to illustrate this chapter's main argument.

First, this chapter sets out the policy rationale framework which now tends to underpin public support for ECEC systems in OECD countries. During a period of Labour government between 1997 and 2010 the English early childhood policy framework underwent a substantial transformation. Although some of this period's achievements have been diluted or abandoned since 2010 , several structural features were consolidated under two subsequent governments.

After exploring the impact of the 1997 - 2010 Labour government on ECEC expansion and innovation in some detail, this chapter proceeds to analyse the barriers to ECEC access that continue to affect children growing up in low-income families in England. This is followed by a brief examination of international evidence for policies and strategies aimed at ensuring more equitable access to high quality ECEC services within similar marketised ECEC systems. Finally, some lessons are drawn from recent English early childhood policymaking experience and their impact. 
In this way this chapter aims to highlight potential implications for other nations at different stages of developing their ECEC policies.

\section{ECEC policy rationales}

OECDmember states employ several policy rationales to justify state support for early childhood education and care provision (Penn, 2011a). The first is the social mobility rationale for investment in ECEC, which has been a major policy driver since the middle of the twentieth century. It aims for a longer-term impact. This presupposes that ECEC helps close the gap in educational attainment between children growing up in low-income families and their better off peers and improves their life chances. In England this policy rationale is reflected in publicly provided early education delivered in state nursery schools or nursery classes attached to primary schools, or in public subsidies to private childcare businesses, like day nurseries, to deliver this provision (Lloyd, 2012a).

In contrast, a second, more recent, policy rationale is an economic wellbeing rationale for public support for ECEC, aiming for more short-term impact. This posits that such provision enables parental - particularly maternal - employment and hence helps eliminate or avoid poverty within families with young children (Lloyd and Potter, 2014). In England and across the UK this rationale is reflected in a system of parental subsidies through the tax and benefits system to help parents pay for childcare costs over and above their children's early education entitlement for children aged under three and for out-of-school care for older children (Penn and Lloyd, 2013). 
Finally, in England and the three devolved UK administrations, as well as in other European and OECD countries, a third, social justice, rationale is also in evidence. This assigns ECEC a role in eliminating social and cultural inequalities and underachievement and in promoting the inclusion of children with transient or permanent learning or physical disabilities (Leseman, 2009).Elsewhere, especially in the Nordic countries, the promotion of gender equality and equitable labour market access for men and women is also clearly seen as part of ECEC's social justice rationale (Ellingsaeter and Leira, 2006).

ECEC rationales interact with other measures aiming to support families with young children, notably parental leave policies (Kamerman and Moss, 2009) and direct fiscal support for childrearing (OECD, 2011a). These interactions add to the challenges facing governments in agreeing a coherent programme of parental leave policies and financial support for families and for ECEC provision (Plantenga and Remery, 2009). Such challenges are magnified in majority world countries, where state support for ECEC is more variable or absent altogether (Penn, 2012).

In recent policy discourses in England and beyond, the first rationale has become closely associated with the approach of Nobel Prize winning economist James Heckman. He applied human capital theory to the role of early childhood education and care in human development (Heckman, 2000). This approach emphasises economic returns from public investments in ECEC and favours the use of costbenefit analyses to measure this. Heckman concluded that substantial public investment in ECEC and its infrastructure, such as the workforce, are highly effective 
and his theory became highly influential in policy circles across the world, helping raise ECEC's profile and promote investment. Nevertheless, Heckman's arguments also attracted considerable criticism. For instance, Buzelli (2015: 16) argues that it undervalues ECEC's contribution to development as it '...provides a limited view of the goals and impact of early education programs on children's development...' which is a concern shared for instance by Moss (2009) and Campbell-Barr and Nygård (2014).

At times, the three main ECEC rationales may be in competition, while the relative importance attached to each in national policymaking may also change between different governments. Shifts in policy emphasis may even occur within the same administration (Lloyd, 2015). Moreover, there may be striking contradictions between the policies informed by these rationales, the chosen policy instruments such as direct service provision, or parental tax credits and benefits, and the format of a country's ECEC services and service systems. This may also be evident where public funding levels are comparable.

An example of such effects is provided in a comparative study by Van Lancker and Ghysels (2011). They demonstrated differences between the social distribution of publicly funded childcare in Sweden and Belgian Flanders. Despite identical per capita expenditure, Sweden, which does not employ a marketised ECEC system, had a more equal social distribution of ECEC services than Flemish Belgium. 
ECEC policy rationales may be affected by prevailing attitudes (Plantenga and Remery,2009:53), national politics (Moss,2012) and changing perspectives on the role of welfare states (Hemerijck,2012). They are directly linked to how and how much state support is invested in an ECEC service system (Penn and Lloyd,2013) and to how its costs are allocated between governments, parents and service providers. The way in which state support is allocated and its delivery model may lead to differences in impact on the services and hence on the children using them.

Frequently, the ECEC funding system's format militates against the successful realisation of the impacts intended by the rationales underpinning public funding. Children growing up in poverty are most at risk from this lack of synergy between ECEC policy intentions and their implementation where a marketised early childhood system is the dominant model(Lloyd and Penn, 2012).This applies to England and indeed to Wales, Scotland and Northern Ireland. The following sections of the present chapter will clarify the nature and operations of so-called marketised ECEC system and provide a more detailed description.

While in principle state support for ECEC is meant to benefit all young children, the three rationales each clearly imply that states must make extra efforts to ensure services reach children at risk of exclusion from ECEC. National (Sylva et al, 2010) and international (Lindeboom and Duiskool, 2013) research has also produced convincing evidence of the need for high service quality in all forms of ECEC provision if it is to promote children's present wellbeing and their future life chances. 
Low quality provision not only poses a greater risk to the life chances of children growing up with disadvantage, but also negatively affects children's direct ECEC experience (Bennett et al, 2012).

Persistent variety both in ECEC services and in the social, legal, regulatory and financing systems supporting them, is a characteristic of early childhood service systems in most OECD member states (OECD, 2006). Such variety is best explained with reference to these systems' differing historical, cultural and institutional context (Rigby, Tarrant and Neuman, 2007; Scheiwe and Willekens, 2009).In Europe for instance, many ECEC systems continue to be split functionally between early education and childcare services, and between services for children aged zero to three and those aged three to school starting age, usually at six (European Commission, 2014); local and central government level responsibilities may be assigned to different departments (Kaga, Bennett and Moss, 2010). In practice this means that the social mobility rationale primarily underpins services for children aged three to six, whereas childcare provision building on the economic wellbeing rationale may apply to either age group. The cross-cutting social justice rationale may be reflected across early education and childcare policies and their associated policy instruments.

The English early childhood service system arguably embodies one of the more problematic manifestations of such dichotomies and contradictions, as this chapter aims to demonstrate. This aspect of the English ECEC system, recent policy developments and their impact on children in low-income families may be easier to interpret if they are first briefly placed within their historical context. 


\section{A brief history of 20th century English ECEC}

Alongside the introduction of free and non-religious compulsory education for children aged 5 and over in 1880 , non-compulsory early education developed in England from the late $19^{\text {th }}$ century onwards. It was only after 1918 that such provision, then largely provided by charitable bodies and faith-based organisations, became eligible for limited and geographically uneven public funding. State funded nursery schools and classes attached to primary schools made an appearance during the 1930s. However, state provided education for 3 to 5 year olds remained firmly targeted at children in low-income families and was mostly found in disadvantaged areas, thus reflecting the social mobility rationale for investment. Early education would not become a universal entitlement in England and across the UK until after 1997, as described below (Penn, 2009).

The parallel growth of childcare provision for the children of employed parents - in practice mothers were to remain the primary target of any policy interventions in this area - followed a different and equally slow trajectory. With the exception of the World War One (WWII) period 1939-1945, childcare largely remained a private parental responsibility, apart from some state day nursery provision catering for the children of lone mothers. The resulting mixed childcare market was made up of small community day nurseries and small private-for-profit childcare businesses, including family daycare businesses run by so-called childminders (Penn, 2009). The institution of the British nanny remained firmly outside the remit of policymaking (Gregson and Lowe, 1994). 
Alongside these two strands of provision a third - social welfare - strand of family support provision had emerged, embodied by a variety of family centres aiming their services at families with young children on low incomes, or with other kinds of problems, including child protection issues. These centres were either run by local government themselves, on their behalf ,or independently by national Non Governmental Organisations (NGOs) like Save the Children or Barnardo's. .Alongside a variety of family support services, parenting training, job-seeking help and adult education, some of these centres also provided early childhood education and care (Lloyd, 2012b)

Free and universal maternity and child health services came into existence in 1948 as a result of the establishment of the British National Health Service (NHS). Although since then there have been attempts to integrate some maternity and child provision into what have come to be known as Sure Start Children's Centres, overall these services remain quite separate from ECEC provision. They are therefore not discussed further within this chapter. Worth noting is that this situation in England contrasts with that in other middle and low-income countries, where health interventions are much more integrated with Early Childhood Development (ECD) provision (Lloyd, 2012c).

As a result, England's ECEC system in the late twentieth century featured an entrenched early education and childcare divide; differences between the remit, qualifications, training, employment conditions and remuneration of the three different early education, childcare and family support workforces and split responsibilities between several departments at central and local government level 
(Penn, 2009).

The three workforces deserve further attention. Qualified early years teachers supported by assistants with childcare qualifications were responsible for delivering early education .in state funded early education; childcare practitioners, many with minimal or no qualifications, worked in the private childcare sector, while a more highly trained family support workforce, including qualified social workers, delivered family support services in family centres.

Table 1 illustrates the early childhood service system inherited by the socialdemocratic Labour Government that came to power in 1997.

Table 1 The English early childhood service system up to 1997

\begin{tabular}{|c|c|c|c|c|c|}
\hline Provision & Format & Ages & Location & Funding & Issues \\
\hline $\begin{array}{l}\text { Early } \\
\text { Education }\end{array}$ & $\begin{array}{l}\text { Part-time ( } 3 \text { to } \\
3.5 \text { hours) or } \\
\text { full- time ( } 6 \text { to } 7 \\
\text { hours) daily } \\
\text { during term- } \\
\text { time. Not } \\
\text { universal. }\end{array}$ & $\begin{array}{l}3 \text { and } 4 \text { year } \\
\text { olds }\end{array}$ & $\begin{array}{l}\text { State nursery } \\
\text { schools, } \\
\text { nursery } \\
\text { classes and } \\
\text { reception } \\
\text { classes }^{1} \text { in } \\
\text { state primary } \\
\text { schools. } \\
\text { Playgroups/ } \\
\text { pre-schools. }\end{array}$ & $\begin{array}{l}\text { Free to } \\
\text { parents. } \\
\text { Central } \\
\text { Government } \\
\text { funded via } \\
\text { Local Authority } \\
\text { Schools } \\
\text { budgets }\end{array}$ & $\begin{array}{l}\text { Insufficient } \\
\text { places; } \\
\text { Very uneven } \\
\text { geographical } \\
\text { distribution } \\
\text { of provision }\end{array}$ \\
\hline Childcare & $\begin{array}{l}\text { Flexible up to } \\
50+\text { hours } \\
\text { weekly all year }\end{array}$ & $\begin{array}{l}0-5 \text { and } \\
\text { 'wrap- } \\
\text { around' for } \\
\text { school-age } \\
\text { children }\end{array}$ & $\begin{array}{l}\text { Private-for- } \\
\text { profit/ not-for- } \\
\text { profit day } \\
\text { nurseries. } \\
\text { Family } \\
\text { daycare (child- } \\
\text { minders). } \\
\text { Municipal day } \\
\text { nurseries and } \\
\text { family centres }\end{array}$ & $\begin{array}{l}\text { Parental fees. } \\
\text { Income related } \\
\text { parental fees } \\
\text { or free in Local } \\
\text { Government } \\
\text { funded } \\
\text { provision. }\end{array}$ & $\begin{array}{l}\text { Insufficient } \\
\text { places } \\
\text { Uneven } \\
\text { geographical } \\
\text { distribution } \\
\text { Socially } \\
\text { segregated } \\
\text { provision. } \\
\text { Variable } \\
\text { quality. }\end{array}$ \\
\hline
\end{tabular}

\footnotetext{
${ }^{1}$ The most junior class in state primary schools admitting children during the year in which they attain compulsory school age
} 


\begin{tabular}{|l|l|l|l|l|l|}
\hline $\begin{array}{l}\text { Social } \\
\text { welfare } \\
\text { provision }\end{array}$ & $\begin{array}{l}\text { Targeted In } \\
\text { response to } \\
\text { identified need }\end{array}$ & 0 upwards & $\begin{array}{l}\text { Municipal and } \\
\text { not-for-profit } \\
\text { family centres }\end{array}$ & $\begin{array}{l}\text { Local } \\
\text { Government }\end{array}$ & $\begin{array}{l}\text { Insufficient } \\
\text { provision. }\end{array}$ \\
\hline
\end{tabular}

Most surprising perhaps about the ECEC system illustrated in Table 1 is the fact that until 1997 there was no universal entitlement to early education for three and four year old children. Such provision was mainly found in Labour Party controlled municipalities. As a response to the continuing absence of sufficient early education, the pre-school playgroup movement had emerged. This was a major maternal selfhelp initiative where groups were sustained with the help of volunteers, mostly mothers (Penn, 2009). Only three countries in Europe would develop this type of private not-for-profit early education provision, the UK, The Netherlands and Ireland (Statham et al, 1990).

Furthermore, until the late 90s there was no state support for parental childcare costs. Childcare was delivered within a mixed market of mostly small private-forprofit and not-for-profit day nurseries and day nursery chains. The provision of social welfare services for families with young children in different types of family centres was often very patchy (Lloyd, 2012b).

\section{English ECEC between 1997 and 2010}

When a Labour government assumed office in 1997, this heralded a 13 year period of sustained ECEC and social welfare innovation and expansion, as Labour won a majority in three elections in a row. The new government set out straight away to make a reality of an accessible, affordable and high quality ECEC system. The policy 
framework developed to guide this process reflected a neo-liberal economics approach, translated into the injection of public funding into the existing mixed market economy of small private childcare businesses (Lloyd, 2008). This had major consequences for children's equitable access within the resulting ECEC system, as will be discussed below. These developments also generated potentially valuable lessons for other countries wishing to build or expand ECEC systems with the help of private sector partners. The consolidation of the mixed market ECEC economy in England persists today.

Within such a mixed ECEC economy as now found in England, private and state ECEC provision co-exist and this system is often referred to as a 'childcare market' (Lloyd and Penn 2012). Since the turn of this century, early education in England is delivered within this childcare market as well as in a parallel system of state provision (Lloyd,2012a). This contrasts with the situation in the Netherlands (Plantenga,2012) and in France (Martin and Le Bihan, 2009) where state funded early education is delivered in nursery departments within primary schools and the market model only characterizes the childcare system.

Among the private-for-profit childcare providers that operate in such markets may be corporate businesses (Penn,2011b). Different geographic and socio-economic contexts, rural versus urban locations and well-to-do versus disadvantaged areas, may lead to a variety of childcare markets within the same country, as in England (Dickens, Taylor, and LaValle,2005). 
In contrast, direct and significant public funding of universal ECEC services has continued in several European countries, including provision for three to six year olds in France (Martin and Le Bihan,2009) and for children aged zero to six in the Nordic countries (Hiilamo,2008). These countries regard ECEC as a 'public good', a concept within economics justifying substantial public investment in both the services themselves and in their infrastructure (Cleveland and Krashinski, 2003). Services and infrastructure are seen as key to ensuring equitable and universal access for all children irrespective of their parents' socio-economic position (Bennett et al, 2012).

A trend emerged towards the introduction of market principles in ECEC and other educational and social services (Penn, 2013). This did not remain confined to England, but featured in other European and OECD countries, including those which had previously featured ECEC systems dominated by public provision. This trend reflected the view that market forces were more efficient and more effective than public agencies in securing ECEC's provision and funding.

Guaranteeing children equitable and universal access to quality ECEC services become particularly problematic if a substantial proportion of providers within such a market are for-profit businesses, as is the case in England (Lloyd and Penn, 2012). The dynamics of competition may drive provision into economically more prosperous areas, as happened in the Netherlands (Noailly and Visser, 2009), where it also affected quality (Akgunduz and Plantenga, 2014). It may also put pressure on staff pay, conditions and in-service training, the largest cost in any 
business and one of the key factors in ensuring service quality (Moss and Bennett, 2010)

As Woodrow describes elsewhere in this volume, an over-reliance on inadequately regulated sizeable private-for-profit nursery chains may lead to major problems for parents and policymakers if such a dominant chain collapses, as happened in Australia in 2008 (Press and Woodrow, 2005; Press and Woodrow, 2009).

In only three European nations, the UK (for children from birth to five years of age), Ireland (for some children from birth to five years of age) and the Netherlands (for children up to three years of age), are parents offered income-related public subsidies such as tax credits or vouchers, to help them buy early childhood provision in such a market (Penn 2013: 3).

For the Labour government the mixed market became the preferred site for ECEC public subsidies; as a result the marketisation and privatisation of childcare provision became much more pronounced after 1997 (Cohenet al., 2004; Penn, 2007).By 2007, private for-profit providers, both corporate chains and sole traders or small partnerships, made up 78 per cent of the UK children's day nursery market, as compared with 11 per cent each supplied by the private not-for-profit and public sectors (Laing and Buisson, 2007).The parallel system of state nursery schools and nursery classes attached to state primary schools did not receive a comparable public funding boost during this period (Lloyd, 2008). 
A major positive development under the Labour government was the introduction of an 'entitlement' to universal part-time early education for three and four year olds in England and in the rest of the UK. Simultaneously, this government consolidated the other two strands of the early childhood service system it had inherited, childcare and social welfare provision, rather than engaging in much more radical reform of the system (Moss, 2014a).No change occurred in the unequal geographical distribution of state nursery schools and classes, which were mainly found in disadvantaged areas, while playgroups were incorporated into the childcare system and effectively became day nurseries. Private-for-profit and not-for-profit childcare businesses, including childminders, but not private nannies, became eligible for direct public subsidies to deliver early education, provided certain quality, including staffing, and safeguarding criteria were met (Penn, 2007).

At central government level ECEC became the responsibility of the Department for Children, Schools and Services. From 2004 ECEC became the responsibility of local government children's services departments, removing the split between education and social services departments. Regulation and inspection duties were transferred from local government to the Office for Standards in Education and Skills (Ofsted) in 2000.By force of the 2006 Childcare Act, such requirements were transformed into the Early Years Foundation Phase, the statutory programme setting standards for the learning, development and care of children from birth to five years old (DCSF, 2008).

It soon transpired that poor families, predominantly large families, families with a disabled child or parent, and minority ethnic families, were no more likely to access 
early education for their three and four year olds than before (Kazimirskiet al., 2006; Speight et al., 2010).The decision to introduce a targeted service in order to improve the uptake of universal early education among disadvantaged three and four year old children (HM Treasury, 2004), led to the piloting of early education for two year old children living with disadvantage (Smith et al., 2009). As it turned out, these children would mostly find places within the private childcare market, where provision quality was demonstrably less (Gambaro et al, 2013),rather than in state nursery schools and classes.

Table 2 illustrates the format of the English early childhood service system and its main public funding by late 2010 , after 13 years of a Labour government.

Table 2 The English early childhood service system in 2010

\begin{tabular}{|c|c|c|c|c|c|}
\hline & $\begin{array}{c}\text { Universal } \\
\text { Early } \\
\text { Education }\end{array}$ & $\begin{array}{c}\text { Targeted } \\
\text { early } \\
\text { Education }\end{array}$ & childcare & $\begin{array}{c}\text { Social } \\
\text { Welfare } \\
\text { provision }\end{array}$ & Issues \\
\hline Format & $\begin{array}{c}15 \text { hours } \\
\text { weekly for } \\
38 \text { weeks } \\
\text { annually }\end{array}$ & $\begin{array}{l}15 \text { hours } \\
\text { weekly for } \\
38 \text { weeks } \\
\text { annually }\end{array}$ & $\begin{array}{l}\text { Flexible up to } \\
50+\text { hours } \\
\text { weekly all year }\end{array}$ & $\begin{array}{l}\text { Targeted In } \\
\text { response to } \\
\text { identified } \\
\text { need }\end{array}$ & $\begin{array}{l}\text { Flexible } \\
\text { delivery only } \\
\text { in private } \\
\text { sector } \\
\text { provision }\end{array}$ \\
\hline Ages & $\begin{array}{c}3 \text { and } 4 \text { year } \\
\text { olds }\end{array}$ & $\begin{array}{l}2 \text { year olds } \\
\text { in low- } \\
\text { income } \\
\text { families }\end{array}$ & $\begin{array}{l}0-5 \text { and } \\
\text { 'wrap-around' } \\
\text { for school-age } \\
\text { children }\end{array}$ & 0 upwards & $\begin{array}{l}4 \text { year olds } \\
\text { increasingly in } \\
\text { state primary } \\
\text { reception } \\
\text { classes }\end{array}$ \\
\hline Location & $\begin{array}{l}\text { State } \\
\text { nursery } \\
\text { schools and } \\
\text { classes; } \\
\text { state primary } \\
\text { school } \\
\text { reception } \\
\text { classes }^{2} \text {; } \\
\text { day } \\
\text { nurseries; } \\
\text { pre-schools }\end{array}$ & $\begin{array}{l}\text { State } \\
\text { nursery } \\
\text { schools and } \\
\text { classes; } \\
\text { day } \\
\text { nurseries; } \\
\text { pre-schools }\end{array}$ & $\begin{array}{l}\text { Private-for- } \\
\text { profit and not- } \\
\text { for-profit day } \\
\text { nurseries. } \\
\text { Family } \\
\text { daycare } \\
\text { (childminders). } \\
\text { Some } \\
\text { municipal } \\
\text { family centres }\end{array}$ & $\begin{array}{l}\text { Municipal } \\
\text { and not-for- } \\
\text { profit family } \\
\text { centres }\end{array}$ & $\begin{array}{l}\text { Lack of } \\
\text { access, } \\
\text { choice and } \\
\text { diversity } \\
\text { disadvantaged } \\
\text { areas. } \\
\text { Socially } \\
\text { segregated } \\
\text { provision. } \\
\text { Variable } \\
\text { quality - lower } \\
\text { in } \\
\text { disadvantaged } \\
\text { areas. }\end{array}$ \\
\hline
\end{tabular}

\footnotetext{
${ }^{2}$ The most junior class in state primary schools admitting children during the year in which they attain compulsory school age
} 


\begin{tabular}{|c|c|c|c|c|c|}
\hline Funding & $\begin{array}{l}\text { Provider } \\
\text { subsidy via } \\
\text { local } \\
\text { government }\end{array}$ & $\begin{array}{l}\text { Provider } \\
\text { subsidy via } \\
\text { local } \\
\text { government }\end{array}$ & $\begin{array}{l}\text { Parental fees. } \\
\text { Income } \\
\text { related } \\
\text { parental fees } \\
\text { or free in } \\
\text { Local } \\
\text { government } \\
\text { funded } \\
\text { provision. }\end{array}$ & $\begin{array}{l}\text { Local } \\
\text { government }\end{array}$ & $\begin{array}{l}\text { Parents } \\
\text { always pay up } \\
\text { to } 33 \% \text { costs. } \\
\text { Only } 33 \% \\
\text { parents } \\
\text { receive any } \\
\text { subsidies, } \\
\text { retrospectively } \\
\text { Fee }\end{array}$ \\
\hline
\end{tabular}

Under Labour, the 2006 Childcare Act (England and Wales) also provided the legal underpinning for a diminished role for local government in respect of co-ordinating early education and childcare provision and the provision of ECEC (HM Government, 2006). The Act imposed on them a 'childcare sufficiency duty.' This meant that they must ensure that enough early education and childcare places were available to meet parental demand. At the same time, there was no longer an expectation that the public authorities themselves would be responsible for filling gaps in provision by themselves providing parallel services within local early education and childcare markets. Municipalities could now only be 'providers of last resort.' This meant that they could only directly provide services if it had proved entirely impossible to locate private providers to deliver these instead.

The Labour government also introduced support for parents to help them afford the costs of childcare needed in addition to early education for three and four year olds, for children aged from birth to three and for after-school and holiday childcare. Parental childcare subsidies in the form of tax credits and employer childcare vouchers were introduced with the express intention of stimulating competition and quality within local childcare markets, thus promoting choice for employed parents (Lewis and Campbell, 2007). Many nursery schools in disadvantaged areas were 
transformed into 'neighbourhood nurseries' designed to prove that even here access to quality childcare provision could be realised, avoiding market failure (Smith et al., 2007).

A new workforce development strategy, coupled with strategic funding, was aimed at promoting the employment of graduates (Mathers et al., 2011) and increasing the level of qualifications of the early childhood workforce as a whole. By gradually bringing the qualifications of the childcare workforce up to a level equivalent to that of the qualified graduate teachers working in state nursery education, the government intended to improve service quality overall. Targets were set for the employment of graduates to lead all ECEC provision, but no true parity was created with qualified teachers in state provision. Even now it remains the case that up to half of practitioners working in childcare provision can be unqualified, as long as they do not have any supervisory responsibilities (DFE, 2014).

As far as ECEC was concerned within the third, social welfare, strand of provision, local authority provision, both day nurseries and multi-functional family centres (Lloyd, 2012b), were largely phased out in favour of the establishment of the multiagency Sure Start Centre initiative, a targeted programme for children aged three and under and their families living in disadvantaged areas. Designed to improve both children's quality of life and school readiness (Belsky et al., 2007),across the UK more than 500 Sure Start Centres came to deliver family support along community development lines, with considerable parental involvement (Belsky et al, 2007). 
The centres' mix of family support provision included parenting education, drop-ins and crèches, family health provision and employment advice. In contrast, early education and childcare were only introduced in a limited number of Sure Start centres after 2004. The Labour Government's failure to create a much more integrated early childhood service system in this and in other respects reflected 'path dependence' in the design of policies and institutions (Penn, 2009). Pierson (2004: 10) used this concept to refer to "...the dynamics of self-reinforcing or positive feedback processes in a political system." He illustrated how it could be usefully applied to the analysis of evolving social processes, dominant institutional arrangements and the power relations operating within these.

By 2004 the government had already decided to extend the reach of Sure Start Children's Centres to every community, some 3000 in all. The resulting 'Children's Centre' model diverged from that of the original Sure Start centres to become more focused on families with young children growing up with disadvantage, rather than offering services to all families within areas of disadvantage (Bate and Foster, 2015).

Despite having dramatically transformed the ECEC landscape in England and the rest of the UK, and having remained committed to the triple policy rationale for investing in ECEC, the Labour government ultimately failed to revisit the neo-liberal principles underlying the marketisation of ECEC. Nor did it question the very basis on which services for young children were being provided (Moss, 2014b). Instead it consistently promoted market principles for the delivery of social welfare services, including ECEC. By the end of Labour's third term, public funding levels for ECEC were being seriously affected by the economic recession (Lloyd and Penn, 2014). 


\section{Poverty and ECEC under Labour}

There were several, often profound, changes of ECEC policy direction during the three successive Labour administrations between 1997 and 2010. The triple rationale underpinning their policy framework, on the other hand, remained unchanged throughout. The policy reorientation almost invariably related to the need to address issues of lack of ECEC quality and accessibility for children growing up in poverty. Quite early on the Labour government announced its intention to eradicate child poverty by 2020 , that is within a generation (Blair, 1999). This commitment was prompted in part by an international focus on poverty eradication (UN, 1995), as well as by Britain's ranking in terms of relative poverty among other industrialised nations (Hills, 2004).

By the Millennium up to one third of British children's lives were affected by poverty (Pantazis et al, 2006). Among the children growing up with disadvantage those from minority ethnic, lone parent or households with a disabled child or parent and those in the private rented housing sector were disproportionally represented. Then, as now, half of all children in poverty in the UK did live within working households (Lloyd, 2006). Consequently, increasing employment opportunities alongside boosting childcare provision in disadvantaged areas could only be part of the policy answer. Low pay was and is a key issue for England. On a par with its economic and academic repercussions for children's life chances (Feinstein, Duckworth and Sabates, 2008), the social costs of poverty for children warranted an urgent and multi-faceted response (Bradshaw, 2001). 
Child poverty levels arguably posed the greatest challenge to realising the Government's Ten Years Strategy for Childcare (HM Treasury, 2004) ambitions for consolidating the early childhood system so that it would reach all children. Truly equitable access to high quality early education and childcare for children growing up in poverty failed to materialise fully, despite a genuine policy intention to achieve this and the Labour government's commitment to redistributive policies (Lloyd, 2006; Lloyd, 2008).

Instead, the gap in educational attainment at primary school entry between children from socio-economically disadvantaged backgrounds and their better-off peers refused to close (Mathers et al., 2007) and private sector childcare prices steadily rose (Paull, 2014). Given the evidence of the potential impact of good quality early education on England's disadvantaged children's life chances (Sylva et al, 2010; Apps et al., 2012),emerging evidence of the risks to ECEC quality within the private childcare sector was especially disturbing. Low quality was identified as a possible risk factor in three and four year old children's unchanged educational outcomes at the end of primary education in a major qualitative study of outcome data for English children at ages five and 11 (Blanden et al., 2016).

Cost constraints limited choice for low-income parents of three and four year old children who wanted to buy childcare hours over and beyond the early education entitlement, particularly in disadvantaged areas (Dickens, Wollny and Ireland, 2012). Although generally of better quality, the available state provision offered less flexibility than the private ECEC sector. Hence the social stratification persisted that 
has characterized English ECEC provision for over a century (Ball and Vincent, 2005).This situation remains unchanged.

Within the English childcare market, there is little choice for parents merely seeking free part-time education for their three and four year olds, but not wanting to pay for additional hours to cover any childcare needs. Most four year olds anyway now enter primary reception classes in the September following their fourth birthday. These children may find places in nursery classes in state primary schools or in a dwindling number of nursery schools. While in disadvantaged areas three quarters of three year olds now attend state nursery classes and schools, the majority of English three year olds receive their free early education in private childcare provision: 64 per cent in 2015 according to official statistics (DFE, 2015a).

However, parents in search of 'free' early education are not especially welcome in private day nurseries, as the nurseries' business model relies on the childcare fees parents pay for hours over and above the 15 free hours. This acts as a perverse incentive to childcare businesses to find strategies to discourage parents from using only the free hours for their children or indeed from using them at all (Hignell, 2014). Private childcare businesses may only offer these hours in restricted sessions or over restricted days and charging parents additional ('top-up') fees appears to be a common practice (House of Commons Public Accounts Committee, 2016).

Such are the challenges for equitable access to quality provision arising from the marketised early childhood system in England. The effect of parental childcare 
subsidies within such markets turns out to be particularly problematic. At the level of supranational bodies such problems have also been identified. For instance, an analysis of Eurostat data suggested that direct provision of social welfare services, including ECEC, reduces income disparities and inequality more than tax breaks for parents (Atkinson and Marlier, 2012). Two papers for OECD also made a strong case for the redistributive impact, i.e. the impact on poverty, of publicly provided services, including childcare, in comparison with parent subsidy models (Verbist et al., 2012; Förster and Verbist, 2012).

As part of its concerted effort at reducing poverty and social exclusion among young children and their families, Labour chose to target not just social welfare services at such children, but also ECEC provision. Targeting early education became a prominent approach intended to address equitable ECEC access issue for children growing up with disadvantage. Its discussion merits a separate section in this paper, as this has remained a key policy tool for securing quality and access.

\section{Targeted versus universal ECEC provision}

Several of the Labour government's policy initiatives took the form of targeting public support for additional provision within a universal ECEC service system, as already described. This aspect of its ECEC policy framework has been adopted and extended by the two successive governments, the $2010-2015$ Coalition government (Lloyd, 2015) and the current Conservative government. But targeting raises issues for practice and of principle. 
After the far-reaching ECEC policy developments of the previous 13 years, further ECEC policy change was slow to appear under the 2010 Coalition Government. The Coalition government honoured its pledge to extend the education entitlement for three and four year olds to 15 hours. But following serious cuts to local government budgets, as part of a programme of economic austerity measures, the number of Children's Centres declined rapidly (Bate and Forster, 2015). Families with young children bore the brunt of cuts in public spending, such as on benefits and social welfare provision and lowering the level of parental eligibility for childcare tax credits (Stewart and Obolenskaya, 2015).

Targeting services remained on the Coalition's ECEC policy agenda. An additional subsidy for primary schools to promote the learning of disadvantaged pupils, the 'pupil premium,' was extended to three and four year olds in early childhood provision, although the 'early years pupil premium' was very low. The Coalition rapidly expanded the targeted offer of part-time education to disadvantaged two year olds, introduced under Labour. No less than 40 per cent of disadvantaged two year olds were meant to benefit by autumn 2014, but 2015 statistics confirmed this target was missed by 40 per cent, while 96 per cent of these children ended up in private provision (DFE, 2015a). Official data confirm its quality is variable (Ofsted, 2015).

Another major targeted initiative is on track for a national roll-out in England by the Conservative government that came to power in 2015 . This is a doubling of the early education entitlement for three and four year old children of parents who meet certain employment conditions. Instead of qualifying for 15 hours weekly, they will be entitled in term time to 30 hours weekly (Frontier Economics, 2016). At the time of 
writing eight local government areas are making preparations to trial the 30 hours entitlement before its September 2017 roll-out in all 150 English local authorities. These municipalities are receiving a clear steer from government to promote uptake of the additional 15 hours among families facing disadvantage (DFE, 2015b). These include families living in rural areas, families where a young child has special educational needs or disabilities (SEND) and Black and minority ethnic families. Yet families in these situations are often disadvantaged and may not meet the employment conditions attached to receipt of the additional entitlement. It remains to be seen how such contradictions are resolved. Implementation problems, including a failure to reach children in low-income families, are widely predicted (Rutter, 2016).

There is a noteworthy contradiction between any forms of ECEC targeting and the approach promoted in an influential review of health inequalities facing England (The Marmot Review, 2010). One of its recommendations was that public funding on early years development, including ECEC, should be focused progressively across the social gradient in an approach that has come to be known as 'proportionate universalism.' The term implies that '.. [policy] Actions must be universal, but with a scale and intensity that is proportionate to the level of disadvantage' (The Marmot Review, 2010, 15).

The issue of targeting has been both topical and controversial for some time within European discussions on quality within evolving ECEC systems (Lindeboom and Duiskool, 2013). The European Commission made its position on targeting clear in a special statement. This addressed the condition of disadvantaged children most at risk from the austerity engulfing Europe: 
The most successful strategies in addressing child poverty have proved to be those underpinned by policies improving the well-being of all children, whilst giving careful consideration to children in particularly vulnerable situations.

(European Commission, 2013: 2)

Arguably, the apparent need for targeting of English services originates in the ECEC service system itself, the childcare market, whose challenges were discussed in earlier sections of this chapter. England is virtually unique in relying on this market to deliver early education, not just childcare. In fact, the English ECEC system is one of the most privatised and marketised ECEC systems in Europe (Penn, 2013).

Some ten years ago, the comparative study of 20 ECEC systems in OECD member states (OECD, 2006), argued that funding models involving parental subsidies in particular, i.e. ECEC markets, may neither ensure children's equal access, nor ECEC affordability and quality:

Without strong state investment and steering of this field, the result will be an insufficient supply of services for those who need those most, leading to increased numbers of children with special needs and learning difficulties; a lack of equity for poorer families; and overall poor quality of provision.

(OECD 2006: 256)

Since 2010 English ECEC policy decisions have become less transparent in terms of their underpinning policy rationales. The phenomenon of successive ECEC policy decisions becoming increasingly opaque in terms of their aims, prompted the Institute for Fiscal Studies, a respected economic think tank, to observe: 
It is not clear whether the main aims are to improve child development, increase parental labour supply or reduce socio-economic inequalities: a clear overarching strategy would help bring some much-needed focus to the debate in this area.

(Brewer et al., 2014: 172)

It is not just the social justice rationale informing English and other nations' ECEC systems, but also its economic wellbeing and social mobility rationales, that are at risk from the economic austerity and growing inequality that is gradually becoming embedded in England. Austerity magnifies the risks associated with childcare markets (Lloyd and Penn, 2014). It affects targeted services as much as universal ones. And its main risk is to children growing up with disadvantage, who stand to benefit the most from such provision, but only if quality is high (van Huizen and Plantenga, 2015).

If no improvement materializes, the outlook for English two year olds in disadvantaged families might be rather bleak in terms of educational outcomes, as 91 per cent received their 15 hours within the private childcare sector, according to the latest official statistics (DFE, 2016). The fact that only 68 percent of eligible two year olds took up a place under the scheme in 2016suggested that the market was not yet working perfectly for them, their parents, childcare businesses and indeed for the government. 
Are there lessons for England to learn from other childcare markets on how to lift children out of poverty and offer them equal access to high quality ECEC provision? Can governments introduce policies which capitalise on the strengths of the private market, enable it to work more effectively and possibly make it more resilient against economic pressures?

\section{Reducing risk within ECEC markets}

Economic pressures within childcare markets attract a variety of governmental responses. Some may be detrimental to access, quality and affordability, such as when governments reduce the level of parent subsidies, as happened in the Netherlands (Akgunduz and Plantenga, 2014) and in England (Lloyd and Penn, 2014). Alternatively, measures can be introduced addressing threatened market failure; these include targeting additional support at children most likely to miss out on access to quality and affordable ECEC. The offer of education to English two year olds forms an example of this. The challenges posed by targeting were already discussed. System transformation, i.e. a thorough reorganisation at multiple levels of existing processes, institutions and relevant policies, is another option, although heavily constrained by economic pressures. In the wake of the collapse of the Australian childcare corporation ABC Learning, Sumsion (2012: 221) recommended an 'ethical audit' framework as an analytical tool for closely monitoring developments within childcare markets and to inform policy developments.

Several publications, including the 2006 OECD thematic survey, a more recent analysis of OECD data (Penn and Lloyd, 2013: 7) and an overview of government 
strategies to ensure quality in childcare markets (Penn and Lloyd, 2014), have suggested ways to improve childcare market operations through various system transformations. Among the most successful forms of government intervention appear to be the promotion of supply-led systems, where providers receive substantial state subsidies and parents pay a reasonable share of costs by means of the introduction of parental fee capping regulations. Where these operate, the growth of the private-for-profit childcare market has been contained in favour of an increased reliance on voluntary, co-operative and state provision (Gambaro et al., 2014). Stringent regulation needs to be paired with any subsidy increases, if price inflation is to be controlled for. This requires a new type of partnership with the private ECEC sector (Penn and Lloyd, 2014).

The case of Norway's viable mixed ECEC economy illustrates these dynamics well (Jacobsen and Vollset 2012).More than 50 per cent of Norwegian 'kindergartens' for children aged one to six are now run by private providers, mostly not-for-profit ones (Haug, 2014).Since the early 2000s this mixed market has featured the fastest increase in uptake among low-income groups; these rates are among the highest for low-income groups anywhere (Ellingsaeter, 2014). Longer-term positive educational and economic outcomes have been demonstrated for children who progressed through this system (Havnes and Mogstad, 2009).

Unlike present day Norway, most countries where a marketised model of ECEC provision prevails have a long way to go in ensuring not only that the services and their infrastructure reflect the underlying policy rationales, but that they serve all children equitably. The2006 OECD thematic survey acknowledged that greater 
choice and opportunities for innovation associated with markets may be preferable to stagnation in public ECEC systems, but it emphasised the need for further research

...on how to create effective social markets, that is, networks of mixed provision in which choice and innovation exist, while maintaining a sense of national and community responsibility for services (OECD, 2006: 119)

England appears to be at a crossroads in terms of the further development of its ECEC system. At present its policies, services and the funding model fail to fully meet the needs of children growing up in poverty. The apparent disconnect between policy rationales and the choice of policy instruments can be traced back to the English ECEC market model (Lloyd and Potter, 2014).

Introducing a social market as envisaged by OECD could mean a new beginning for English ECEC policy. But '....any initiatives need to be systematically developed, and well-funded, for improvements to be sustainable; in other words, changes need to be implemented at a macro as well as at a micro level.' (Penn and Lloyd, 2014: 46).

\section{Conclusions}

While the need to reconsider the direction of current ECEC policy and the triple rationales for government support is undeniably urgent. It also appears useful to reflect on the strengths of the current English ECEC system. Three characteristics stand out when attempting to take the perspective of any country trying to learn from the English experience: 
1. There exists a genuine commitment on the part of the state to invest substantial public money into the ECEC system, guided by three rationales which emphasise the importance of longer-term outcomes for children, the immediate economic well-being of families with young children and children's present enjoyment of ECEC services

2. There exists a genuine commitment to achieving an inclusive ECEC system which reaches out to children growing up in low-income households, children with transient or permanent physical or learning disabilities and children with English as an additional language

3. There is a clear awareness of the crucial role played by early childhood leaders, teachers, practitioners and entrepreneurs in ensuring beneficial outcomes and good quality experiences for all children using ECEC provision and a commitment to developing a commensurate workforce strategy

The present overview of critical junctures in English ECEC policy development demonstrates the challenge of finding appropriate and interconnected policy instruments to make a reality of these commitments. For example, the uncomfortable interface between supply-side and demand-side funding for early education and childcare respectively highlight the importance of a logical and simple funding model; information on childcare costs (Rutter, 2016) demonstrate the risks of price inflation in the absence of appropriate government intervention in market operations and the lack of consistency in the provision of ECEC within children's centres highlight the need to revisit the role and location of ECEC within social welfare provision. 
If the English ECEC system is to make a serious contribution to lifting poor children out of poverty and improving their life chances, then the prevailing hegemonic childcare market discourse should itself become an issue for debate. Any debate aimed at achieving public consensus about optimal ways forward should not be centred on the perfection of a system based on competition and individual choice, as Moss argues strongly (2014b). In contrast, this should form part of a much wider examination of the values and principles underpinning the present ECEC system.

One point should guide any such debate. This is that, by itself, even universal, comprehensive good-quality ECEC does not 'inoculate' against the adverse effects of child poverty (Lloyd and Potter, 2014). Multiple approaches by multiple actors as part of a comprehensive anti-poverty strategy are needed for reducing poverty and addressing its consequences for young children's educational achievements, health and safety, nutrition, housing and access to public services within the families in which they grow up. This constitutes the greater challenge.

\section{References}

Akgunduz, Y.E. and Plantenga, J. (2014) 'Childcare in the Netherlands: lessons in privatisation', European Early Childhood Education Research Journal, 22(3): 379385.

Apps, A., Mendolia, S. and Walker, I. (2012) The Impact of Pre-school and Adolescents' Outcomes: Evidence from a Recent English Cohort. Discussion Paper No 6921. Bonn: Institute for the Study of Labour - IZA. 
Atkinson, A.B. and Marlier, E. (eds) (2012) Income and Living Conditions in Europe.

Brussels: Eurostat/EU Commission. Available from:

http://ec.europa.eu/eurostat/documents/3217494/5722557/KS-31-10-555-

EN.PDF/e8c0a679-be01-461c-a08b-7eb08a272767

Ball, S.J. and Vincent, C. (2005) 'The "Childcare Champion?” New Labour, social justice and the childcare market', British Educational Research Journal, 31(5): 557570.

Bate, A. and Foster, D. (2015) Sure Start England. Briefing Paper Number 7257, 15 July. London: House of Commons Library. Available from:

http://researchbriefings.files.parliament.uk/documents/CBP-7257/CBP-7257.pdf

Belsky J., Barnes J. and Melhuish E.(eds) (2007) The National Evaluation of Sure Start - Does Area-based Early Intervention Work? Bristol: The Policy Press. Bennett, J., Gordon, J. and Edelmann, J. (2012) Early Childhood Education and Care(ECEC) for Children from Disadvantaged Backgrounds: findings from a European Literature Review and two Case Studies. Final Report. Brussels: European Commission. Available from:

http://ec.europa.eu/dgs/education culture/repository/education/policy/school/doc/ece c-report en.pdf

Blair, T. (1999) 'Beveridge revisited: a welfare state for the twenty-first century' in R. Walker (ed) Ending Child Poverty: Popular Welfare for the 21st Century? Bristol: The Policy Press. pp.

Blanden, J., Del Bono, E., McNally, S. and Rabe, B. (2016) 'Universal pre-school education: the case of public funding with private provision', The Economic Journal, 126(May): 682-723. 
Bradshaw, J. (ed) (2001) Poverty: The Outcomes for Children. ESRC Occasional paper 26. London: family Policy Studies Centre.

Brewer, M., Cattan, S., and Crawford, C. (2014) 'State support for early childhood education and care in England', in C. Emmerson, P. Johnson H. and Miller (eds) IFS Green Budget 2014. London: Institute for Fiscal Studies.

Buzelli, C.A. (2015) 'How human capital theory sells early education short: revaluing early education through the capabilities approach', in Lightfoot-Rueda, T. and Peach, R.L. (eds) Global Perspectives on Human Capital Theory in Early Childhood Education - Reconceptualizing Theory, Policy and Practice. Basingstoke: Palgrave Macmillan. pp. $215-240$.

Campbell Barr, V.J.G. and Nygård, M.2014'Losing sight of the child? Human capital theory and its role for early childhood education and care policies in Finland and England since the mid-1990s', Contemporary Issues in Early Childhood 15(4): 346359.

Cleveland, G., and M. Krashinski. 2003. Starting Strong: Financing ECEC Services in OECD Countries. Paris: Organisation for Economic Co-operation and Development.

Cohen, B., Moss, P., Petrie, P. and Wallace, J.(2004) A New Deal for Children? Reforming Education and Care in England, Scotland and Sweden, Bristol: The Policy Press.

Department for Children, Schools and Families (2008) Statutory Framework for the Early Years Foundation Stage. London: Department for Children, Schools and Families. 
Department for Education (2014) Statutory Framework for the Early Years Foundation Phase. London: DFE. Available from:

https://www.gov.uk/government/uploads/system/uploads/attachment data/file/33550 4/EYFS framework from 1 September 2014 with clarification note.pdf Department for Education (2015a) Provision for Children Under Five Years of Age in England. January 2015. Statistical First Release. London: DFE and ONS.

https://www.gov.uk/government/uploads/system/uploads/attachment data/file/43759 8/SFR20-2015 Text.pdf

Department for Education (2015b) Childcare Bill. Policy Statement. London:

Department for Education. Available from:

https://www.gov.uk/government/uploads/system/uploads/attachment data/file/48251 7/Childcare Bill Policy Statement 12.03.2015.pdf

Department for Education (2016) Provision for Children Under Five Years of Age in England. January 2016. Statistical First Release. London: DFE and ONS.

Dickens, S., Taylor, J. and La Valle, I.(2005) Local Childcare Markets: a Longitudinal Study, SSU Research Report 016. London: Department for Education and Science. Dickens, S., Wollny, I. and Ireland, E. (2012) Childcare Sufficiency and Sustainability in Disadvantaged Areas. Research Report DFE-RR246. London: Department for Education.

Ellingsaeter, A.L. (2014) 'Towards universal quality early childhood education and care: the Norwegian model', in L. Gambaro, K. Stewart and J. Waldfogel (eds) An Equal Start? Providing Quality Early Education and Care for Disadvantaged Children. Bristol: The Policy Press. pp. 53-76.

Ellingsaeter, A.L. and Leira, A. (eds) (2006) Politicising Parenthood in Scandinavia Gender Relations and Welfare States. Bristol: The Policy Press. 
European Commission (2013) Investing in Children - Breaking the Cycle of

Disadvantage. Commission Recommendation of 20.02.2013. Brussels: European Commission.

European Commission (2014) Key Data on Early Childhood Education and Care in Europe. A Eurydice and Eurostat report. Brussels: European Commission.

Feinstein, L., Duckworth, K. and Sabates, R. (2008) Education and the Family Passing Success across the Generations. Abingdon: Routledge.

Fitzgerald, D. and Kay, J. (2016) Understanding Early Years Policy. London: Sage.

Förster, M. and G. Verbist, G. (2012)Money or Kindergarten? Distributive Effects of Cash Versus In-kind Family Transfers for Young Children. OECD Social, Employment and Migration Working Papers No 135. Paris: OECD.

Frontier Economics (2016) Feasibility Study into Evaluating the Labour and Childcare Market Impacts of Tax-Free Childcare and the Free Early Education Entitlement. A report prepared for HM revenue and Customs and the Department for Education. HMRC Research Report 406. London: Frontier Economics. Available from:

https://www.gov.uk/government/uploads/system/uploads/attachment data/file/49916 8/Feasibility study into evaluating the labour and childcare market impacts of $\underline{\text { Tax-Free Childcare and the Free Early Education Entitlement.pdf }}$ Gambaro, L., Stewart, K. and Waldfogel, J. (2013) A Question of Quality: do Children from Disadvantaged Backgrounds Receive Lower Quality Early Years Education and Care in England? CASE papers, CASE/171. Centre for the Analysis of Social Exclusion, London School of Economics and Political Science, London, UK. 
Gambaro, L., Stewart, K. and Waldfogel, J. (eds) (2014) An Equal Start? Providing Quality Early Education and Care for Disadvantaged Children. Bristol: The Policy Press.

Gregson, N. and Lowe, M. (1994) Servicing the Middle Classes. London: Routledge. Haug, P. (2014) 'The public-private partnership in ECEC provision in Norway', European Early Childhood Education Research Journal, 22(3): 366-378.

Havness, T. and Mogsted, M (2011) 'Money for nothing? Universal childcare and maternal employment', Journal of Public Economics, 95 (11-12): 1455-1465.

Heckman, J. (2000) 'Policies to foster human capital', Research in Economics, 54(1): $3-56$.

Hemerijck, A. (2012) 'Two or Three Waves of Welfare State Transformation?' In N. Morel, B. Palier and J. Palme (eds) Towards a Social Investment Welfare State? Ideas, Policies and Challenges. Bristol: The Policy Press. pp. 33-69.

Hignell, K. (2014) The Practicalities of Childcare: An Overlooked Part of the Puzzle? London: Citizens Advice. Available from:

https://www.citizensadvice.org.uk/Global/Migrated Documents/corporate/thepracticalities-of-childcare---an-overlooked-part-of-the-puzzle.pdf

Hiilamo, H. (2008) Early Childhood Education and Care. Promoting Children's Welfare in the Nordic Countries. Reports of the Ministry of Social Affairs and Health 2008: 15. Helsinki, Finland: Ministry of Social Affairs and Health.

Hills, J. (2004) Inequality and the State. Oxford: Oxford University Press. HM Government (2006) The Childcare Act 2006. London: Her Majesty's Stationary Office. 
HM Government (2013) Devolution of Powers to Scotland, Wales and Northern Ireland. Guidance. London: Cabinet Office, Scotland Office, Welsh Office, Northern Ireland Office. Available from: https://www.gov.uk/guidance/devolution-of-powers-toscotland-wales-and-northern-ireland\#overview HM Treasury (2004) Choice for Parents, the Best Start for Children: A Ten year Strategy for Childcare. London: The Stationary Office. Available from: http://dera.ioe.ac.uk/5274/2/02 1204 pbr04childcare 480-1.pdf House of Commons Committee of Public Accounts (2016) Entitlement to Free Early Years Education and Childcare. Fourth Report of Session 2016-17. London: House of Commons. Available from:

http://www.publications.parliament.uk/pa/cm201617/cmselect/cmpubacc/224/22402. $\underline{\mathrm{htm}}$

Van Huizen, T. and Plantenga, J. (2015) Universal Child Care and Children's Outcomes: A Meta-analysis of Evidence from Natural Experiments. Utrecht School of Economics Tjalling C. Koopmans Research Institute Discussion Paper Series 15-13. Utrecht: University of Utrecht. Jacobsen, K. and Vollset, G. (2012)'Publicly available and supported early education and care for all in Norway', in E. Lloyd and H. Penn (eds) Childcare Markets - Can they Deliver and Equitable Service? Bristol: The Policy Press in association with the University of Chicago Press. pp. 115-130. Kaga, J., Bennett, J. and Moss, P. (2010) Caring and Learning Together - A Crossnational Study on the Integration of Early Childhood Care and Education within Education. Paris: UNESCO. Available from: http://unesdoc.unesco.org/images/0018/001878/187818E.pdf 
Kamerman, S. and Moss, P. (eds) (2009) The Politics of Parental Leave Policies: Children, Gender, Parenting and the Labour Market. Bristol: The Policy Press. Kazimirski, A., Southwood, H. and Bryson, C.(2006) Childcare and Early Years Provision for Minority Ethnic Families. London: National Centre for Social Research. Laing and Buisson(2007) Children's Nurseries UK Market Report 2007. London: Laing \& Buisson.

van Lancker, W., and Ghysels, J. (2011)Who Reaps the Benefits? The Social Distribution of Public Childcare in Sweden and Flanders. GINI Discussion Paper 10. Amsterdam: AIAS. Available from:http://www.uvaaias.net/uploaded files/publications/DP10-VanLancker,Ghysels-1.pdf Leseman, P. (2009) Tackling Social and Educational Inequalities through Early Childhood Education and Care in Europe. A Eurydice report. Brussels: European Commission. Available from:

http://eacea.ec.europa.eu/about/eurydice/documents/098EN.pdf Lewis, J. and Campbell, M.(2007) 'Work/family balance policies in the UK since 1997: a new departure? Journal of Social Policy, 36(3): 365-81.

Lindeboom, G-J. and Duiskool, B-J. (2013) Quality in Early Childhood Education and Care. Brussels: European Parliament. Available from:

http://www.europarl.europa.eu/RegData/etudes/etudes/join/2013/495867/IPOLCULT ET(2013)495867(ANN01) EN.pdf Lloyd, E. (2006) 'Children, poverty and social exclusion’ in C. Pantazis, D. Gordon and R. Levitas (eds) Poverty and Social Exclusion in Britain: The Millennium Survey. Bristol: The Policy Press. pp. 315-345. 
Lloyd, E. (2008) 'The interface between childcare, family support and child poverty strategies under New Labour: tensions and contradictions', Social Policy \& Society, 7 (4): 479-494.

Lloyd, E. (2012a) 'The marketisation of early years education and childcare in England', in L. Miller and D. Hevey (eds) Policy Issues in the Early Years. London: Sage. pp. 107- 121.

Lloyd, E. (2012b) 'Centre-based services in the early years', in M. Hill, G. Head, A. Lockyer, B. Reid and R. Taylor (eds) Children's Services: Working Together. London: Longman Pearson. pp. 104-115.

Lloyd, E. (2012c) ‘Childcare markets: an introduction', in E. Lloyd and H. Penn (eds) Childcare Markets - Can they Deliver and Equitable Service? Bristol: The Policy Press. pp.

Lloyd, E. (2015) 'Early childhood education and care in England under the Coalition Government', London Review of Education, 33(2): 144-156. Available from: http://ingentaconnect.com/content/ioep/c/re/2015/00000013/00000002/art00012 Lloyd, E., and Penn, H. (eds) (2012) Childcare Markets - Can they deliver an equitable service? Bristol: The Policy Press in association with the University of Chicago Press.

Lloyd, E. and Penn, H. (2014) 'Childcare markets in an age of austerity', European Early Childhood Education Research Journal, 22(3): 386-396.

Lloyd, E. and Potter, S. (2014) Early Education and Childcare and Poverty -Working Paper Prepared for the Joseph Rowntree Foundation. London: University of East London. Available from: http://roar.uel.ac.uk/3865/

The Marmot Review (2010) Fair Societies - Healthy Lives. Strategic Review of Health Inequalities in England Post-2010. London: University College London. 
Available from; http://www.instituteofhealthequity.org/projects/fair-society-healthylives-the-marmot-review

Martin, C., and Le Bihan, B. (2009)'Public Childcare and Preschools in France,' in K. Scheiwe and H. Willekens (eds) Childcare and Preschool Development in EuropeInstitutional Perspectives. Basingstoke: Palgrave Macmillan. pp. 57-71.

Mathers, S., Sylva, K. and Joshi, H. (2007) Quality of Childcare Settings in the Millennium Cohort Study. Research Report SSU/2007/FR/025. London: Department for Education and Skills.

Mathers, S., Ranns, H., Karemaker, A., Moody, A., Sylva, K., Graham, J. and SirajBlatchford, I. (2011) Evaluation of the Graduate Leader Fund. Final Report.

Research Report DFE-RR144. London: Department of Education.

Mathers, S. and Smees, R. (2014) Quality and Inequality - Do Three- and Four-yearolds in Deprived Areas Experience Lower Quality Early Years Provision? London: Nuffield Foundation. Available from:

http://www.nuffieldfoundation.org/sites/default/files/files/Quality inequality childcare mathers 2905 14.pdf

Moss, P. (2009) There are Alternatives! Markets and Democratic Experimentalism in Early Childhood Education and Care. Working Papers in Early Childhood Development. The Hague: Bernard van Leer Foundation and Bertelsmann Stiftung. Moss, P. (2014a) 'Early childhood policy in England 1997-2013: anatomy of a missed opportunity', International Journal of Early Years Education, 22(4): 346-358.

Moss, P. (2014b) Transformative Change and Real Utopias in Early Childhood Education. Abingdon: Routledge.

Moss, P., and Bennett, J. (2010) Working for Inclusion: An Overview of European Union Early Years Services and their Workforce. Edinburgh: Children in Scotland. 
Noailly, J., and S. Visser, S.(2009)'The Impact of market forces on the provision of childcare: insights from the 2005 Childcare Act in the Netherlands', Journal of Social Policy 38(3):477-498.

OECD (2006) Starting Strong II. Early Childhood Education and Care. Paris: Organisation for Economic Cooperation and Development.

OECD (2011) How can we do better for our families? Paris: Organisation for Economic Co-operation and Development

OECD (2014) Starting Strong IV - Monitoring Quality in Early Childhood Education and Care. Paris: Organisation for Economic Cooperation and Development.

Ofsted (2015) Early Years. The Report of Her Majesty's Chief Inspector of Education, Children's Services and Skills 2015. London: Ofsted

Pantazis, C, Gordon, D. and Levitas, R. (eds) (2006) Poverty and Social Exclusion in Britain: The Millennium Survey. Bristol: The Policy Press.

Paull, G. (2014) 'Can Government Intervention in Childcare be Justified?' Economic Affairs 34(1): 14-34.

Penn, H. (2007) ‘Childcare market management: How the United Kingdom Government has reshaped its role in developing early childhood education and care', Contemporary Issues in Early Childhood 8(3): 192-207.

Penn, H. (2009) 'Public and private: The history of early education and care institutions in the United Kingdom', in: K. Scheiwe and H. Willekens (eds) Child Care and Preschool Development in Europe. Institutional Perspectives. Ashgate: Palgrave Macmillan. pp. 105-125. 
Penn, H. (2011a) 'Policy rationales for early childhood services', International Journal of Child Care and Education Policy 5(1): 1-16.

Penn, H. (2011b) 'Gambling on the market: The role of for-profit provision in early childhood education and care', Journal of Early Childhood Research 9(2): 150-161 Penn, H. (2012) 'Raw and emerging childcare markets', in E. Lloyd and H. Penn (eds) Childcare Markets - Can they Deliver an Equitable Service? Bristol: The Policy Press. pp. 173-187.

Penn, H. (2013) 'The business of childcare in Europe', European Early Childhood Research Journal,21(4): 432-456.

Penn, H. and Lloyd, E. (2013) The Costs of Childcare. London: Childhood Wellbeing Research Centre. Available from:http://www.cwrc.ac.uk/documents/CostsofchildcareJuly2013.pdf Penn, H. and Lloyd, E. (2014) 'How can government ensure that early care and education is of high quality in a market system? Learning from international experience', in T Wolfe (ed) 'Childcare’: Business or Profession? Dublin: Start Strong. pp.11 - 52. Available from: http://www.startstrong.ie/files/Childcare Business or Profession Full Report Web Version.pdf

Plantenga, J. and Remery, C. (2009) The Provision of Childcare Services: A Comparative Review of 30 European Countries. Brussels: European Commission. Available from: http://www.fruehechancen.de/fileadmin/PDF/Archiv/the provision childcare services.pdf Press, F. \& Woodrow, C. (2009) The Giant in the Playground: Investigating the reach and implications of the corporatisation of child care provision, in D. King \& G. Meagher (eds) Paid Care in Australia: Profits, Purposes and Practices. University of 
Sydney Press.

Press, F. \& Woodrow, C. (2005) Commodification, Corporatisation and Children's Spaces. Australian Journal of Education 49 (3) 278- 297.

Rigby, E., Tarrant, K. and Neuman, M.J. (2007) 'Alternative policy designs and the socio-political construction of childcare', Contemporary Issues in Early Childhood, 8(2): 98-108.

Rutter, J. (2016) Childcare costs survey 2016. London: Family and Child Care Trust. Scheiwe, K. and Willekens, H. (eds) (2009) Child Care and Preschool Development in Europe - Institutional Perspectives. New York: Palgrave Macmillan.

Smith, T., Coxon, C. and Sigala, M. (2007) National Evaluation of the Neighbourhood Nurseries Initiative: Implementation Study, SSU Research Report 021. London: Department for Education and Skills.

Smith, R., Schneider, V., Purdon, S., La Valle, I., Wollny, Y., Owen, R., Bryson, C., Mathers, S., Sylva, K. and Lloyd, E. (2009) Early Education Pilot for Two Year Old Children - Evaluation. Research report DCSF-RR134. London: Department for Children, Schools and Families. Available from: http://dera.ioe.ac.uk/10651/1/DCSF$\underline{\text { RR134.pdf }}$

Speight, S., Smith, R., Coshall, C. and Lloyd, E. (2010) Towards universal early years provision: Analysis of take-up by disadvantaged families from recent annual childcare Surveys. Research Report FE-RR066. London: Department for Education. Available from: http://dera.ioe.ac.uk/11574/1/DFE-RR066-WEB.pdf Statham, J., Lloyd, E., Moss, P., Melhuish, E. and Owen, C. (1990) Playgroups in a Changing World. London: Her Majesty's Stationary Office.

Stewart, K., and Obolenskaya, P. (2015) The Coalition's Record on the Under Fives: Policy, Spending and Outcomes 2010-2015. Working Paper 12, Centre for Analysis 
of Social Exclusion. London: London School of Economics. Available from: http://sticerd.Ise.ac.uk/dps/case/spcc/WP12.pdf

Sumsion, J. (2012) 'ABC Learning and Australian early education and care: A retrospective ethical audit of a radical experiment', in E. Lloyd and H. Penn (eds) Childcare Markets - Can they Deliver an Equitable Service? Bristol: The Policy Press. pp. 209-225.

Sylva, K., E. Melhuish, P. Sammons, I. Siraj-Blatchford, and B. Taggart (2010) Early Childhood Matters: Evidence from the Effective Pre-School and Primary Education Project. London: Routledge.

United Nations (1995) The Copenhagen Declaration and Programme of Action. World Summit on Social Development, 6-2 March, New York. New York: UN Department of Publications.

Verbist, G., M. Förster, and Vaalavuo, M. (2012)The Impact of Publicly Provided Services on the Distribution of Resources: Review of New Results and Methods. OECD Social, employment and Migration Working Papers No 130. Paris: OECD. 